\title{
Absorption of Different Doses of Fat Soluble and Water Miscible Preparations of Vitamin E in Children with Cystic Fibrosis
}

\author{
J. T. HARRIES^ and D. P. R. MULLER† \\ From The Hospital for Sick Children, and The Institute of Child Health, University of London
}

\begin{abstract}
Harries, J. T., and Muller, D. P. R. (1971). Archives of Disease in Childhood, 46, 341. Absorption of different doses of fat soluble and water miscible preparations of vitamin $E$ in children with cystic fibrosis. A comparison of the intestinal absorption of water miscible and fat soluble preparations of $\alpha$ tocopheryl acetate in children with cystic fibrosis showed the water miscible preparation to be more efficiently absorbed. In the absence of liver disease, a daily dose of $1 \mathrm{mg} / \mathrm{kg}$ body weight of a water miscible preparation can be expected to correct any pre-existing vitamin $\mathrm{E}$ deficiency within 2 months of starting treatment, and is adequate for subsequent maintenance.
\end{abstract}

Vitamin E deficiency due to intestinal malabsorption is frequently found in children with cystic fibrosis (CF) (Bennett and Medwadowski, 1967; Muller and Harries, 1969). The mechanisms that influence the absorption of vitamin $E$ in the normal child are not yet fully understood and the precise cause of its malabsorption in CF is not clear. Bile salt micelles play an important role in the solubilization and absorption of dietary lipids from the intestinal lumen (Hofmann and Borgstrom, 1962), and it is probable that incorporation of monoglycerides and fatty acids into the bile salt micelle is of major importance for the solubilization of fat soluble vitamins (Badley, 1970). Since monoglycerides and fatty acids are liberated from dietary triglyceride by the action of pancreatic lipase, the defective lipolysis in patients with CF might be anticipated to interfere with the absorption of fat soluble vitamins such as vitamin $E$. Water miscible preparations of vitamin $\mathrm{E}$, therefore, by being less dependent on this solubilizing system, are likely to be more efficiently absorbed than fat soluble preparations.

In a preliminary communication we reported that a water miscible preparation of $\alpha$-tocopheryl acetate was better absorbed than a fat soluble

\footnotetext{
Received 27 October 1970.

$\star$ Present address : Department of Gastroenterology, St. Bartholomew's Hospital, London E.C.1.

t Present address: Division of Clinical Chemistry, Clinical Research Centre, Harrow, Middlesex.
}

preparation in children with CF when given in a large dose of $10 \mathrm{mg} / \mathrm{kg}$ per day over a period of one month (Harries and Muller, 1969). This paper presents the conclusions of this study, together with an investigation of the use of a smaller dose of vitamin $\mathrm{E}$ which would be more suitable for therapeutic use.

\section{Patients and Methods}

Fifty children aged 6 months to $14 \frac{1}{2}$ years with CF were studied. None had evidence of liver disease and all were treated with moderate reduction in dietary fat together with pancreatic enzymes in the form of Pancrex V. $\ddagger$ In addition vitamin supplements were given in the form of Abidec§ (contains no vitamin E).

Vitamin E was administered orally as DL- $a$-tocopheryl acetate I either as a fat-soluble preparation in tablet form (Ephynal), or as a clear water miscible preparation which contained a surface-active agent (Cremaphor EL, $16 \mathrm{~g} / 100 \mathrm{ml}$ ) and glycerine.

Trial 1. We had previously (Harries and Muller, 1969) chosen 30 patients and randomly assigned them to 1 of 3 groups. 10 received no vitamin E supplement and served as a control group, 10 received the fat soluble preparation, and 10 children received the water miscible preparation. Both preparations were given as a

I Pancrex V: Paines and Byrne Ltd.,

S Abidec: Parke Davis and Co. Ltd., Each $0.6 \mathrm{ml}$ contains: vitamin A, 5000 IU; vitamin $B_{6}, 0.5 \mathrm{mg}$; vitamin $\mathrm{D}, 400 \mathrm{IU}$; nicotinamide, $5 \mathrm{mg}$; vitamin $B_{1}, 1 \mathrm{mg}$; vitamin $C, 50 \mathrm{mg}$. Dose $1<\mathrm{yr}=0.3 \mathrm{ml} / \mathrm{dy} ;>1 \mathrm{yr}=0.6 \mathrm{ml} / \mathrm{dy}$.

T Roche Products Ltd., 
Results of Oral Administration of Two Preparation $\varepsilon_{j}$

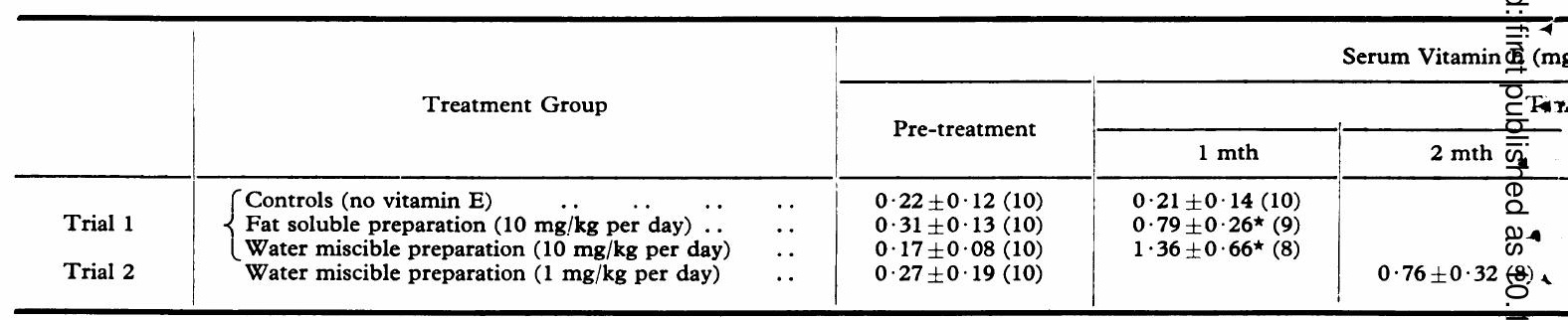

Figures in parentheses denote number of children; ${ }^{\star} \mathrm{P}$ for difference between means $<0.05$.

Mean serum vitamin $\mathrm{E}$ concentration in 22 children without malabsorption $0.80 \mathrm{mg} / 100 \mathrm{ml} \pm 0.18$ (1 SD)

single dose of $10 \mathrm{mg} / \mathrm{kg}$ per day taken after breakfast for a total period of 1 month. Serum levels of vitamin $E$ were determined before and at the end of this period and 1 month after discontinuing vitamin $\mathrm{E}$.

Trial 2. Another 10 children received the water miscible preparation in a dose of $1 \mathrm{mg} / \mathrm{kg}$ per day taken as a single dose after breakfast for a period of 8 months. Serum levels of vitamin E were determined immediately before starting treatment, at intervals of 2 months during the treatment period, and at 2 and 4 months after discontinuing vitamin $\mathrm{E}$.

In both trials a number of children failed to complete the planned period of treatment for a variety of reasons; the numbers in each group are given in the Table.

Serum vitamin $\mathrm{E}$ was measured in triplicate on aliquots of $0.3 \mathrm{ml}$ serum by the method of Quaife, Scrimshaw, and Lowry (1949) with the following modifications. Bathophenanthroline was used as an indicator instead of alpha, alpha ${ }^{1}$-dipyridyl (Tsen, 1961); a correction was made for serum carotene by reading its extinction at $450 \mathrm{~m} \mu$ (Bieri et al., 1964); and orthophosphoric acid was added in order to minimize photoreduction of ferric ions (Tsen, 1961).

\section{Results}

Trial 1. In the control group serum vitamin $E$ remained unchanged, but in both treatment groups levels rose to within normal limits; the mean rise in serum vitamin $E$ was significantly greater $(P<0.05)$ in the children who received the water miscible preparation.

Trial 2. The results are shown in the Table. The mean pretreatment concentration of serum vitamin $\mathrm{E}$ was similar to that in Trial 1; after 2 months of treatment the mean level had risen to $0.76 \mathrm{mg} / 100 \mathrm{ml}$ which did not differ from the mean level achieved after 1 month of the fat soluble preparation in Trial 1. There was only a slight rise in serum levels during the remainder of the 8-month treatment period. After discontinuing treatment for 2 months the mean level had fallen to $0.44 \mathrm{mg} / 100 \mathrm{ml}$ and after 4 months to 0.32 $\mathrm{mg} / 100 \mathrm{ml}$; these values did not differ significantly from the pretreatment level of $0.27 \mathrm{mg} / 100 \mathrm{ml}$.

\section{Discussion}

The higher mean levels of serum vitamin $\mathrm{E}$ achieved after 1 month of treatment with the water miscible preparation, compared with the fat soluble preparation in Trial 1, suggested that the former preparation was more efficiently absorbed. This confirmed the results of oral loading tests (Harries and Muller, 1969) and was further supported by the findings that the mean level of serum vitamin $E$ after treatment for 2 months with the water miscible preparation in a dose of $1 \mathrm{mg} / \mathrm{kg}$ per day (Trial 2) was similar to that in the children who had received 10 times the dose of the fat soluble preparation $(10 \mathrm{mg} / \mathrm{kg}$ per day) for one month.

It is suggested that the water miscible preparation is more efficiently absorbed because it is less dependent on the solubilizing properties of mixed micelles within the intestinal lumen. If this is so, then it is necessary to presuppose that micellar solubilization plays an important role in the luminal phase of vitamin $\mathrm{E}$ absorption. In the experimental animal, McMahon and Thompson (1969) found vitamin E to be better absorbed from a mixed micellar solution than from an emulsion, but Kelleher, Davies, and Losowsky (1969) were unable to detect any difference between its absorption from a suspension of Tween 80 or from an oily suspension. In normal young adults we have observed a water miscible preparation of vitamin $\mathrm{E}$ to be better absorbed than a fat-soluble one (Harries and Muller, unpublished), and similar findings are reported by Adam and Körner (1968). The precise mechanisms by which mixed micelles enhance absorption of such non-polar lipids as the fat soluble vitamins are not clear. It is likely that at least part of the function of mixed micelles is the 
Tocopheryl Acetate to Children with Cystic Fibrosis

ml) Mean $\pm 1 \mathrm{SD}$

\begin{tabular}{|c|c|c|c|c|c|}
\hline Starting Treatme & & & Tim & r Discontinuing & \\
\hline $4 \mathrm{mth}$ & $6 \mathrm{mth}$ & $8 \mathrm{mth}$ & $1 \mathrm{mth}$ & $2 \mathrm{mth}$ & $4 \mathrm{mth}$ \\
\hline $0.71 \pm 0.47(7)$ & $0.89 \pm 0.55(6)$ & $0 \cdot 84 \pm 0.33(6)$ & $\begin{array}{l}0 \cdot 35 \pm 0 \cdot 10(5) \\
0 \cdot 400 \pm 0 \cdot 23(4)\end{array}$ & $0 \cdot 44 \pm 0 \cdot 23(6)$ & $0.32 \pm 0.25(6)$ \\
\hline
\end{tabular}

carriage of insoluble substances to their absorptive sites on the brush borders of epithelial cells (Mysels, 1969). Thereafter, there is probably a complex series of events, which controls the movement of substances across the membranes of the absorptive cell; for instance there is evidence that bile salts and several other detergents can affect the permeability of cell membranes and in this way could influence transfer of substances into cells (Gibaldi and Feldman, 1970).

Though medical literature during the past 30 years contains an abundance of reports concerning the clinical uses of vitamin $\mathrm{E}$ in man, the claims made in many of these reports remain uncorroborated. In recent years, however, a few careful and critical studies have stimulated a renewed interest in the possible role of vitamin $\mathrm{E}$ in the causation of human disease. Haemolytic anaemia (Oski and Barness, 1967) and subcutaneous oedema (Ritchie et al., 1968) in premature babies, and reduced red blood survival in adults (Horwitt, Century, and Zeman, 1963) have been observed in vitamin $\mathrm{E}$ deficiency states. In children with abetalipoproteinaemia, preliminary findings have suggested a relation between the severe vitamin $\mathrm{E}$ deficiency which occurs in this condition and the retinal and neurological abnormalities that subsequently develop (Muller, Harries, and Lloyd, 1970). In children with $\mathrm{CF}$, deposition of ceroid (Kerner and Goldbloom, 1960), focal muscle necrosis similar to that seen in animals with muscular dystrophy due to vitamin E deficiency (Oppenheimer, 1956), and creatinuria which was reversed by vitamin $\mathrm{E}$ therapy (Nitowsky, Gordon, and Tildon, 1956; Nitowsky et al., 1962) have all been reported. It is doubtful, however, whether the high incidence of sterility found in males with CF is related to vitamin $\mathrm{E}$ deficiency (Kaplan et al., 1968; Holsclaw and Schwachman, 1969).

Though the necessity for vitamin $\mathrm{E}$ therapy in CF remains unproven, it seems reasonable to include it in the routine management of children with this condition. A total daily dose of $1 \mathrm{mg} / \mathrm{kg}$ per day of a water miscible preparation of $\alpha$ tocopheryl acetate can be anticipated to correct any pre-existing vitamin $\mathrm{E}$ deficiency after 2 months of starting treatment, and will thereafter maintain adequate serum levels. This dosage, however, does not apply to patients with liver involvement, whose requirements for vitamin $\mathrm{E}$ may be far greater, particularly when there is biliary obstruction (Muller and Harries, 1969).

We thank Dr. A. P. Norman for permission to study his patients, Dr. June K. Lloyd for advice and guidance, and the Joint Research Board of the Institute of Child Health and The Hospital for Sick Children for support (J.T.H). Roche Products Ltd. provided financial support (D.P.R.M.).

\section{REFERENCES}

Adam, W., and Körner, W. F. (1968). Untersuchungen zur Resorption der Vitamine A und E. Internationale Zeitschrift für Vitaminforschung, 38, 160.

Badley, B. W. D. (1970). Bile salts. Canadian Medical Association fournal, 102, 159 .

Bennett, M. J., and Medwadowski, B. F. (1967). Vitamin A, vitamin $E$ and lipids in serum of children with cystic fibrosis or congenital heart defects compared with normal children. American fournal of Clinical Nutrition, 20, 415.

Bieri, J. G., Teets, L., Belavady, B., and Andrews, E. L. (1964). Serum vitamin $\mathbf{E}$ levels in a normal adult population in the Washington, D.C. area. Proceedings of the Society for Experimental Biology and Medicine, 117, 131.

Gibaldi, M., and Feldman, S. (1970). Mechanisms of surfactant effects on drug absorption. Fournal of Pharmaceutical Sciences, $59,579$.

Harries, J. T., and Muller, D. P. R. (1969). Absorption of water miscible and fat soluble preparations of vitamin $E$ in cystic fibrosis. In Proceedings of the 5th International Cystic Fibrosis Conference, p. 298. Ed. by D. Lawson. Cystic Fibrosis Research Trust, London.

Hofmann, A. F., and Borgstrom, B. (1962). Physico-chemical state of lipids in intestinal content during their digestion and absorption. Federation Proceedings, 21, 43.

Holsclaw, D. S., and Schwachman, H. (1969). Genital function in cystic fibrosis. In Proceedings of the 5th International Cystic Fibrosis Conference, p. 308. Ed. by D. Lawson. Cystic Fibrosis Research Trust, London.

Horwitt, M. K., Century, B., and Zeman, A. A. (1963). Erythrocyte survival time and reticulocyte levels after tocopheral depletion in man. American fournal of Clinical Nutrition, 12, 99. 
Kaplan, E., Schwachman, H., Perlmutter, A. D., Rule, A., Khaw, K.-T., and Holsclaw, D. S. (1968). Reproductive failure in males with cystic fibrosis. New England fournal of Medicine, 279, 65.

Kelleher, J., Davies, T., and Losowsky, M. S. (1969). Absorption and tissue uptake of $\alpha$-tocopherol in the rat. Biochemical Fournal, 114, 74P.

Kerner, I., and Goldbloom, R. B. (1960). Investigations of tocopherol deficiency in infancy and childhood. American fournal of Diseases of Children, 99, 597.

McMahon, M., and Thompson, G. R. (1969). Comparison of absorption of a polar and non-polar lipid from micellar solutions and emulsions. Gut, 10, 1054.

Muller, D. P. R., and Harries, J. T. (1969). Vitamin E studies in children with malabsorption. Biochemical fournal, 112, 28P.

Muller, D. P. R., Harries, J. T., and Lloyd, J. K. (1970). Vitamin $\mathrm{E}$ therapy in A-Betalipoproteinaemia. Archives of Disease in Childhood. 45, 715 .

Mysels, K. J. (1969). Contribution of micelles to the transport of a water-insoluble substance through a membrane. Advances in Chemistry Series, 86, 24.

Nitowsky, H. M., Gordon, H. H., and Tildon, J. T. (1956). Studies of tocopherol deficiency in infants and children. IV. The effect of alpha tocopherol on creatinuria in patients with cystic fibrosis of the pancreas and biliary atresia. Bulletin of the fohns Hopkins Hospital, 98, 361.
Nitowsky, H. M., Tildon, J. T., Levin, S., and Gordon, H. H. (1962). Studies on tocopherol deficiency in infants and children. VII. The effect of tocopherol on urinary, plasma and muscle

creatine. American fournal of Clinical Nutrition, 10, 368.
Oppenheimer, E. H. (1956). Focal necrosis of striated muscle in an infant with cystic fibrosis of the pancreas and evidence of lack of absorption of fat-soluble vitamins. Bulletin of the Fohns Hopkins Hospital, 98, 353.

Oski, F. A., and Barness, L. A. (1967). Vitamin E deficiency: a previously unrecognized cause of hemolytic anemia in the $\overparen{D}$ premature infant. Fournal of Pediatrics, 70, 211.

Quaife, M. L., Scrimshaw, N. S., and Lowry, O. H. (1949). A ڤ micromethod for assay of total tocopherols in blood serum. Fournal of Biological Chemistry, 180, 1229.

Ritchie, J. H., Fish, M. B., McMasters, V., and Grossman, M. (1968). Edema and hemolytic anemia in premature infants. New England fournal of Mediciine, 279, 1185.

Tsen, C. C. (1961). An improved spectrophotometric method for determination of tocopherols using 4,7-diphenyl-1,10-phenanthroline. Analytical Chemistry, 33, 849.

Correspondence to $\mathrm{Dr}$. J. T. Harries, The Hospital is for Sick Children, Great Ormond Street, London WC1N 3JH. 